\title{
Privatisation of Agro-Industrial Parastatals and Anglophone Opposition in Cameroon
}

\section{PIET KONINGS}

\section{INTRODUCTION}

Privatisation has become a key instrument in the stabilisation and structural adjustment programmes imposed on Africa by the Bretton Woods institutions. It is an essential part of an overall strategy to open up African economies to market forces and promote private sector development. African governments are under considerable pressure from international donors to sell public enterprises to domestic and foreign private capital, especially since these enterprises are considered to have performed dismally. Given their troubled economic conditions and acute dependence on foreign financial flows, African governments have officially accepted privatisation so as not to forfeit the international support crucial for their political survival.

Several authors, however, have observed that the actual number of privatisations has remained modest in Africa.' They point to various technical and financial constraints as well as sociopolitical factors which can explain this curious finding. Interestingly, some factors reflect the same political concerns that had led to the creation of so many public enterprises in the years after independence: inability to attract foreign investment to the politically and economically unstable African nations, absence of a welldeveloped domestic entrepreneurial class, and the pursuit of patron-client relationships by African 'patrimonial' states. ${ }^{2}$ Another important factor is the resistance to privatisation from civil society, in particular by professional bodies, student organisations and trade unions, since privatisation often involves the sale of public property to well-placed nationals or to foreign enterprises and generally results in massive lay-offs of workers.

Surprisingly little attention has been devoted to regional opposition to privatisation. In this article I focus on regional opposition in Cameroon which arose after 15 July 1994, when the government was forced by

Piet Konıngs, African Studies Centre, Leiden

Journal of Commonwealth \& Comparative Politics, Vol 34, No 3 (November 1996), pp 199-217 PUBLISHED BY FRANK CASS, LONDON 
international donors to announce the privatisation of 15 public enterprises, notably in the transport and agro-industrial sectors. The most prominent among them was the Cameroon Development Corporation (CDC), founded in 1946/47. The CDC is one of the oldest and by far the largest agroindustrial parastatal in Cameroon. Its estates are located mainly in the coastal areas of Anglophone Cameroon, and its immense contribution to regional development has been highly valued by the regional population. I will argue here that the virulent regional opposition to the privatisation of the CDC cannot be fully grasped without reference to what has come to be called the 'Anglophone problem'. This problem poses a major challenge to the efforts of the post-colonial state to forge 'national unity' and 'national integration', and it has led to the reintroduction of 'federalism' and 'secession' into the national political discourse.

The root of the problem may be traced back to 1961, the birth of the Federal Republic of Cameroon. This marked the reunification of two territories which had undergone different colonial experiences after the First World War, when the erstwhile German Kamerun Protectorate was partitioned into French and British Mandate/Trust Territories. It also marked the start of a unique experiment in federalism in Africa. However, federalism in Cameroon turned out to be 'more shadow than reality'. Contrary to Anglophone expectations, federalism did not create an equal partnership between the two parties which could preserve the cultural heritage and identity of the Anglophone minority. It proved a mere transitory phase in the total integration of the Anglophone region into a strongly centralised, unitary state. This gradually spawned an Anglophone consciousness: the feeling of being 'marginalised', 'exploited' and 'assimilated' by the Francophonedominated state and by the Francophone population as a whole. Not until the political liberalisation process of the early 1990s did parts of the Anglophone elite begin openly organising in various associations and pressure groups to protest against the subordinate position of the Anglophones and to put forward claims for self-determination and autonomy. Although the major Anglophone movements initially called for a return to the federal state, the Biya government's persistent refusal to discuss such constitutional reforms later forced them to adopt a secessionist stand.

The government announcement on 15 July 1994 of the CDC privatisation was seen in Anglophone Cameroon as a further step in the dismantling of the Anglophone colonial legacy by the Francophone-dominated state. As a consequence, all regional parties, associations and pressure groups were inclined to forget their differences and form a united front against any attemp to sell the CDC to French or Francophone interests. One ethnic group in the coastal area of Anglophone Cameroon, the Bakweri, was particularly concerned with the announced privatisation of the corporation. Since they claimed ownership of the CDC lands, the Bakweri felt betrayed at not having been previously consulted, and they warned the government that the CDC could not be sold to non-natives without Bakweri consent.

\section{PRIVATISATION OF THE CDC}

Privatisation has been put forward by the international donors as one of the magic formulas to cure the ailing Cameroonian economy. For many years, the economy of Cameroon had been viewed as one of the rare success stories in Africa. This was not without foundation: Cameroon's economic performance was impressive, registering a phenomenal growth rate of 6-7 per cent during the period $1970-86 .{ }^{4}$ However, as Hugon was the first to point out, this optimistic view tended to ignore certain weaknesses in the domestic economy which constantly threatened the 'growth miracle' - in particular the economy's almost total dependence on the export of agricultural raw materials and, more recently, of oil. ${ }^{5}$ This particular weakness became increasingly manifest from the mid-1980s onwards, when the sharp fall in the prices of these commodities on the world market, together with the 40 per cent depreciation of the US dollar relative to the CFA franc, plunged the domestic economy into severe crisis. This situation was worsened by large-scale mismanagement, embezzlement and capital flight estimated at FCFA 150 billion a year - one-quarter of the annual national budget. Apparently the much-trumpeted slogans of 'rigour and moralisation' which Paul Biya had coined on succeeding Ahmadou Ahidjo as president in 1982 had been nothing more than hollow phrases. After some procrastination, the government was forced to adopt a structural adjustment plan (SAP) in 1988/89, containing such conventional prescriptions as big cuts in public expenditures, increased state revenues, privatisation and thoroughgoing liberalisation. ${ }^{6}$

At the start of the economic crisis, there were some 175 public enterprises in the country, employing around 80,000 people. A considerable number of agro-industrial parastatals had been created or expanded after independence with the aid of international donors. 'These public enterprises served both economic and political ends. Besides being potential avenues to economic modernisation and growth, they allowed the government to engage in prebendal politics and to cement a 'hegemonic alliance', incorporating the country's emerging elite into the state apparatus." A 'patrimonial logic' existed in many African post-colonial states, but it was particularly forceful in Cameroon, a country with stark ethnic and regional cleavages. It is beyond any doubt that this logic contributed to the poor performance of most public and para-public enterprises. ${ }^{9}$ Prior to the economic crisis, the Cameroonian government was subsidising parastatal 
sector losses to the tune of some 150 billion CFA francs a year. Though many of the oil revenues were initially kept in secret bank accounts abroad, their primary function soon became the covering of parastatal deficits.

From the very start of the economic crisis, the World Bank made parastatal reform a cornerstone of its lending conditions. Given the growing budgetary constraints, the Biya government officially agreed to co-operate. In May 1987 it appointed a national commission to recommend reform measures for the parastatal sector. One year later the commission reported back to the president, having determined which institutions should be liquidated, sold to the private sector or rehabilitated. However, few public enterprises were effectively privatised, only six between 1988 and $1994 .^{10}$ Van de Walle has offered the following reasons for the slow pace of privatisations:

Although the government is proceeding with care on the politically sensitive issue of lay-offs, this does not appear to be the major constraint on rapid implementation of the reform agenda. Rather, intra-elite competition and haggling over the rents freed up by privatisation, along with the lack of technical expertise within the state, served to slow down the process of institutional reform."

Dissatisfied with the government's performance, the World Bank threatened in early 1994 to suspend a credit of US\$75 million to Cameroon if the government did not accelerate the process of privatisation. Subsequently, on 15 July of that year, the government announced the privatisation of 15 large public enterprises. Five agro-industrial parastatals were among them, including the CDC. For various reasons, the announced privatisation of the CDC brought on great commotion in the country, particularly in Anglophone regions.

The CDC is the largest agro-industrial enterprise in the country. It is the second largest employer of labour, surpassed only by the government. It formerly employed 25,000 workers. At present, it still engages about 14,000 permanent workers and a few thousand seasonal and casual workers. It is one of the few agro-industrial enterprises in the world that specialises in a variety of crops, its four major ones being rubber, palm oil, tea and bananas. Following independence and reunification in 1961, the corporation expanded its cultivated area from 20,000 to 40,000 hectares, with the help of huge loans from several well-known financial institutions, including the World Bank, the International Development Association (IDA), the European Development Fund (FED), the Commonwealth Development Corporation (COMDEV) and the (French) Central Fund for Economic Cooperation (CCCE).

The CDC is, furthermore, one of the country's oldest enterprises. Its history is closely linked with the political and economic history of Anglophone Cameroon. It was founded in 1946, but its roots can be traced back to the German colonial period (1884-1914). ${ }^{12}$ During that period many large-scale private plantations were created on the fertile, volcanic soils around Mount Cameroon in the coastal area of the present Anglophone Cameroon. The establishment of a plantation economy in the region led to the expulsion of the original occupants of the land, notably the Bakweri, into prescribed native reserves. ${ }^{17}$ With the British occupation in $1914 / 15$, the property of the German planters was confiscated and turned over to the Custodian of Enemy Property. When, shortly afterwards, the British took over the administration of the area, the plantations were merged and a government department was formed to manage them. By 1922, however, the British Mandate Authority had already decided to get rid of them, as the administrative costs of maintaining them were said to be prohibitive. It then seriously considered returning the plantation lands to the original owners, but in the end it dropped the idea. Instead, it came to the conclusion that it would be in the best interest of the territory and its inhabitants to turn the plantations back into the hands of foreign private enterprise. At an auction held in London in November 1924, almost all the estates were bought by the former German owners.

At the start of World War Two, the German estates were again expropriated by the Custodian of Enemy Property; after the war, a decision had to be reached once more on how to dispose of the properties. The educated Bakweri elite, organised in the so-called Bakweri Land Committee. immediately began agitating for the retrieval of its ancestral lands. It sent several petitions, first to the British Crown, and subsequently to the United Nations, as Britain had assumed responsibility for administration of the territory under United Nations Trusteeship after the war. However, after considerable deliberations, the British Trusteeship Authority declined once again to surrender the ex-German plantation lands to the original owners. Instead, it announced in November 1946 that they would be leased to a newly established statutory corporation, the Cameroon Development Corporation (CDC).

This corporation came into being with the passage of two ordinances in December 1946. The first of these, the Ex-Enemy Lands (Cameroons) Ordinance No. 38 (1946), provided for the acquisition of the ex-German plantation lands which had been vested in the Custodian of Enemy Property for the duration of World War Two. Under the terms of this ordinance, the Governor of Nigeria, responsible for the administration of British Cameroons, was to declare them 'native lands' and hold them in trust for the common benefit of all the inhabitants of the territory. The second ordinance, the Cameroons Development Corporation Ordinance No. 39 (1946), 
provided for the setting up of the corporation. All the lands acquired by the governor under the first ordinance were to be leased to this corporation for a period of 60 years. Significantly, the corporation was charged with a double responsibility: it was to develop and manage the approximately 100,000 hectares of estate lands in the interests of the people of the Trust Territory, and it was to provide for the spiritual, educational and social welfare of its employees. After fulfilling all its obligations, the corporation was to pay direct taxes to the Government of Nigeria and all profits were to be used for the benefit of the people of the Trust Territory.

The CDC was of great importance to regional development. Some students of plantation agriculture, such as Beckford, ${ }^{14}$ have blamed the persistent poverty and underdevelopment of Third World economies on this mode of production. In the case of the CDC, however, this thesis finds little support. The corporation has been a major instrument of modernisation and is largely credited with whatever socioeconomic development has occurred in Anglophone Cameroon. It has created employment for many men and women. It has constructed numerous roads. It has supplied mater and electricity. It has built and staffed schools. It has awarded a substantial number of scholarships. It has provided medical care for a large proportion of the local population. It has stimulated the supply of goods and services to itself and its workers. And it has played a key role in the commercialisation and modernisation of peasant production, as an intermediary in marketing the Bakwerı peasantry's banana production in the 1950 s and in the establishment of regional smallholders' oil palm and rubber schemes from the early $1960 \mathrm{~s} .{ }^{15} \mathrm{As}$ a result, the CDC has often been called the economic lifeline of Anglophone Cameroon.

The government announcement of the privatisation of this important agro-industrial enterprise was all the more shocking to the Anglophone population since the CDC (i) had been one of thecking to the Anglophone Cameroon to perform relatively well until the the rare public enterprises in able to survive the crisis mainly becautil the economic crisis, (ii) had been able to survive the crisis mainly because the management and the workers had agreed to adopt a series of drastic adjustment measures, and (iii) was on the way to economic recovery following the 50 per cent devaluation of the CFA franc in early 1994.

From its inception, the CDC has generally yielded positive results, though these fluctuated over the years. In the three years preceding the crisis (1983/84-1985/86), the corporation was still making preceding the crisis totalling FCFA 3.2 billion. The crisis, the corporation's financial situation: suffered a loss ofiod 1986/87-1990/91 it suffered a loss of about FCFA 18 billion. Evidently the sharp fall in commodity prices on the world market was the principal cause of the near bankruptcy of the corporation. Nevertheless, other factors also contributed to the emergence and continuation of the crisis. First, there was the political elite's inability or unwillingness to control the import of cheap tea and palm oil, which impeded CDC sales on the domestic market. Second, there have been frequent reports of involvement by the managerial elite in massive embezzlement, reckless expenditure, waste and struggles for power often based on ethnic and regional considerations. Managerial problems were aggravated by the fact that the government was no longer prepared to render financial assistance to the ailing parastatal during the crisis. To save the company from total collapse, the management and the trade unions on the CDC estates agreed to adopt a series of adjustment measures aimed at cost reduction and productivity increase. On 23 August 1987 the union presidents agreed with management on a substantial increase in the productivity to be required of estate workers. For example, the daily quota required from tea pickers was raised from 26 to 32 kilograms of green leaves. As the corporation's financial position continued to deteriorate, management proposed further austerity measures to the union presidents. Following negotiations, a new agreement was signed on 6 January 1990 , which entailed drastic cuts in the salaries and fringe benefits of all workers and managerial staff, amounting to some 30 to 40 per cent of their previous incomes. The corporation formerly supplied the workers with free housing, water, electricity and medical facilities; henceforth they would be obliged to make substantial contributions towards these services. The most draconian measure, however, was the introduction of a compulsory savings scheme forcing the workers to save at least 15 per cent of their basic wages and salaries for the corporation's recovery. ${ }^{16}$

This managerial strategy for economic recovery was reinforced in 1989/90. The IMF- and World Bank-inspired SAP obliged the CDC management to sign a four-year performance contract (1989/90-1993/94) with the government, stipulating that the corporation was to achieve a set of objectives relating to plantation management, production costs, quantity and quality of output, and personnel productivity. In return, the government was to write off some of the corporation's debts amounting to FCFA nine billion and to exempt it from payment of certain taxes. The various adjustment measures did bring some relief to the company's liquidity problems but, owing to the contınuing decline in commodity prices, its existence remained precarious. It was not until early 1994 that any bright prospects for economic recovery appeared. The devaluation of the CFA franc made CDC products more competitive on the world market. Then, a few months later, the government surprisingly announced privatisation of the corporation, which prompted vehement protest actions in Anglophone Cameroon. 
THE 'ANGLOPHONE PROBLEM'

The intense opposition in Anglophone Cameroon to the announced privatisation of the CDC can only be fully understood within the wider political context of what has been called the 'Anglophone problem'.${ }^{17}$ This problem emerged after the political elites of two territories with different colonial legacies - one French and the other British - had agreed in 1961 on the formation of a federal state. Anglophone expectations that federalism would create equal partnership proved unrealistic. During negotiations on the federal constitution, notably at the Foumban Conference from 17 to 22 July 1961, it had already been evident that the bargaining power of the Francophone delegation was far greater than that of the Anglophones. Compared to the Francophone region, the size and population of the Anglophone region was small, comprising only nine per cent of the area and about a quarter of the total population of the federation. Even more important, by the time of these negotiations the former French Trust Territory of Cameroon was already an independent state, having been renamed the Republic of Cameroon, while the British Trust Territory of Southern Cameroons was, under the terms of the 1961 United Nations plebiscite, still to achieve its independence by joining the sovereign Republic of Cameroon. Capitalising on his territory's 'senior' status, Ahmadou Ahidjo, the then Prime Minister of the Republic of Cameroon and leader of the Francophone delegation, was able to dictate the terms for federation. Although John Ngu Foncha, the then Prime Minister of Southern Cameroons and leader of the Anglophone delegation, had proposed a loose form of federalism, which he regarded as a guarantee for preservation of the cultural heritage and identity of the Anglophone minority, Ahidjo eventually forced him to accept a highly centralised form of federalism. Ahidjo, who was to become the President of the Federal Republic of Cameroon, looked upon federalism merely as an unavoidable transitory phase in the total integration of the Anglophone minority into a strongly centralised, unitary state. To achieve this objective, he employed several tactics. One was to play off Anglophone political factions against each other and eventually integrate them into a single party, the Cameroon National Unıon (CNU). Another was to eliminate from positions of power any Anglophone leaders who remained committed to federalism, replacing them by others who favoured a unitary state. Still another tactic was to create 'clients' among the Anglophone elite. By granting top posts in the federal institutions and in the single party to representatives of significant ethnic and regional groups in the Anglophone region, he tried to control these groups. Finally, he did not shrink from repressing any opposition. Through these and other tactics he succeeded in abolishing the federation on 20 May
1972. His justification for this 'glorious revolution' was that federalism fostered regionalism and impeded economic development.

A growing number of the Anglophone elite, however, were inclined to attribute the emergence of 'regionalism' and lack of economic development not to federalism per se, but rather to the hegemonic tendencies of the Francophone-dominated state. They began complaining of the loss of regional autonomy and the subordinate position of the Anglophone minority in the unitary state. Their numerous grievances were mainly political, economic and cultural. In particular these concerned their under-representation and their inferior role in the national decision-making councils, the neglect of the region's infrastructure and the exploitation of its rich economic resources, especially oil, and the attempts at 'Frenchification'. ${ }^{18}$

To reduce the danger of any united Anglophone action against the Francophone-dominated state, Ahidjo decided after the 'glorious revolution' of 20 May 1972 to divide the Anglophone territory into two provinces, the South-West and North-West Provinces. In making his decision he was well aware of the internal contradictions within the Anglophone community between the coastal/forest people (the South West Province) and the Grassfield people (the North-West Province). One of the major reasons for these internal conflicts was the transfer of political power from the south-west to the north-west elite at the end of the 1950s. Following this transfer, the north-west elite began asserting its presence. It soon became ubiquitous in the higher levels of government and in high nongovernmental positions. In pre-empting for itself the choicest jobs as well as the best lands in the south-west, it provoked strong resentment among south-westerners to north-west domination. ${ }^{19}$ South-west sentiments were intensified by the fact that the 'entrepreneurial' north-westerners have gradually succeeded in dominating most sectors of the south-west economy, particularly trade, transport and housing. ${ }^{20}$ Another source of the southwest-north-west divide was the UN plebiscite of 1961: on that occasion, the south-west had shown considerable sympathy for alignment with Nigeria, but the choice for Cameroon prevailed, mainly on the strength of the northwest votes. A final source of tensions was the massive labour migration from the north-west to the south-western plantations and the subsequent settlement of north-western workers in the south-west.

Lack of unity and severe repression precluded the Anglophone elite from openly expressing its grievances about Francophone domination until 1982, when Biya took power. Following the limited degree of liberalisation introduced by the new president, Anglophones began voicing their longstanding grievances. They strongly protested when the Biya government in 1984 changed the country's official name from 'United Republic of Cameroon' to simply 'Republic of Cameroon'. They recalled that the new 
name was the same as the one Ahidjo had given to independent Francophone Cameroon before reunification. Regional tensions in Anglophone Cameroon were fuelled when it became clear that the president's ethnic group, the Beti, were increasingly monopolising political and economic power. Like his predecessor, Biya attempted to divide the Anglophones. One of his strategies was to replace north-westerners, who held key positions in the south-west, by south-westerners.

Given the Anglophone frustration with the Francophone-dominated state, it was not surprising that the first opposition party in the country was formed in Anglophone Cameroon. In 1990 the Social Democratic Front (SDF) was founded at Bamenda, the capital of the North West Province. Its chairman was John Fru Ndi, a librarian by profession, who was to achieve great popularity among the urban masses because of his great courage and populist style of leadership. Its massive launching rally on 26 May 1990 ended in the killing of six young Anglophones by government troops.

Under considerable internal and external pressure, the Biya government eventually introduced a larger measure of political liberalisation. In December 1990 it announced multi-partyism as well as a certain degree of freedom of mass communication, association and holding of public meetings and demonstration. As a result, one could observe the establishment of several political parties, associations and pressure groups, and private newspapers in Anglophone Cameroon, which began to express and represent Anglophone interests. The SDF then spread its influence from the North West Province to the South West Province, soon becoming the major opposition party in Anglophone Cameroon. However, it proved far more popular in the northwest than in the south-west, as the south-west elite continued to be suspicious of the aspirations of the predominantly north-western party leadership, fearing renewed north-west domination. Personal animosities, on the other hand, prevented the south-west elite from forming a strong south-western party. For some time the SDF was instrumental in turning the Anglophone region into one of the hot-beds of rebellion in the country, organising several fierce confrontations with the regime in power, especially in the 1991 'ghost town' campaign. ${ }^{21}$ Paradoxically, despite its great contribution to Anglophone consciousness and action, the party began presenting itself as a 'national' rather than an 'Anglophone' party, evidenced by its growing Francophone membership. Henceforth, Anglophone interests would be represented first and foremost by several newly created Anglophone associations and pressure groups. Some of these, such as the Free West Cameroon Movement (FWCM) and the Ambazonia Movement of Fon Gorji Dinka, advocated outright secession. Most, however, initially championed a return to the federal state, the major ones being the Cameroon Anglophone Movement (CAM) and the All Anglophone Congress (AAC).
These Anglophone associations and pressure groups have regularly organised demonstrations, strikes and boycotts in their struggles against the Francophone-dominated unitary state. The participation of various strata of the Anglophone population in these actions demonstrates that the 'Anglophone problem' can no longer be perceived as simply and solely an elitist problem. Interestingly, the actions are directed partly against the discourses, myths and symbols produced by the unitary state. Anglophone movements have boycotted the celebration of the national holiday on 20 May, the 'day of the 1972 glorious revolution', declaring it a 'day of mourning'. They called upon Anglophones to celebrate their own holidays instead, namely the 'day of independence' on 1 October and the 'day of the plebiscite' on 11 February. On these days there have been attempts by CAM activists to hoist the federation flag. This challenge was answered by the regime with extreme brutality. In addition, the Anglophone movements have begun referring to Anglophone Cameroon as the 'Southern Cameroons', the name of the territory during the British Trusteeship. The reintroduction of this name serves at least two purposes. First, these movements allege that the union between Anglophone and Francophone Cameroon has proceeded without any constitutional base, because the proper procedures for the enactment and amendment of the federal constitution were not followed by Ahidjo. In this perspective, Anglophone Cameroon still finds itself in the pre-reunification phase as the Trust Territory of the Southern Cameroons. Consequently, the United Nations should shoulder its political responsibility for this territory and condemn the 'annexation of the Southern Cameroons' by the Republic of Cameroon. The hoisting of the United Nations flag in Anglophone Cameroon in recent years is a symbol of the Anglophone belief in the continuing responsibility of the United Nations for the Southern Cameroons. A second purpose of the reintroduction of the name Southern Cameroons is to lay a historical and geographical foundation for Anglophone identity.

Confronted with the Biya government's persistent refusal to discuss a return to the federal state, Anglophone movements declared the 'zero option' in 1993/94, total independence for the Southern Cameroons. They have since engaged in a diplomatic offensive to gain international support for the Anglophone cause. This offensive has focused particularly on the United Nations and the Commonwealth. ${ }^{22}$

Missions to the United Nations undertaken by members of the Anglophone Standing Committee of the AAC and the newly created Southern Cameroons National Council (SCNC) to seek support for the Anglophone struggles for a return to the federal state or for secession have generated wide publicity for the Anglophone cause, but have failed to yield any tangible results. The Anglophone Standing Committee and the SCNC 
have also done their utmost to prevent the Republic of Cameroon from being admitted into the Commonwealth. The Biya government applied for membership in 1989. It hoped that Commonwealth membership would create new political and economic openings outside the French sphere of influence and help improve its strained relationship with the Anglophone community. The latter proved to be wishful thinking, however. The Anglophone movements made strong appeals to Commonwealth members to reject the application of the Republic of Cameroon, drawing attention to the Biya government's persistent oppression of the Anglophone minority. The Commonwealth was asked instead to seriously consider granting the Southern Cameroons either full membership or a special status in the organisation, for the Southern Cameroons was more likely to meet the historical and linguistic conditions for admission than was the Republic of Cameroon. Eventually, the Anglophone campaign failed. Although the Republic of Cameroon did not yet fulfil the conditions for Commonwealth membership stipulated in the 1991 Harare Declaration - the establishment of a democratic system, good governance and respect for human rights - it was nevertheless admitted to the Commonwealth on 1 November 1995. Most Commonwealth members argued that Cameroon's admission would bring pressure to bear upon the Biya government to introduce political reforms. It is noteworthy that their argument has been supported by the chairman of the SDF, John Fru Ndi. SCNC leaders felt frustrated, however. They now appear to have developed a new strategy. At the November 1995 Commonwealth summit at Auckland in New Zealand, their delegation pleaded for a Quebecstyle referendum for the Southern Cameroons and filed an application for a separate Southern Cameroons membership of the Commonwealth

The SCNC has set 1 October 1996 as the date for the declaration of independence of the Southern Cameroons. The chances of international recognition of an independent Southern Cameroons state remain slim, but the SCNC is hopeful that its diplomatic offensive will at least raise international awareness to the point where military intervention by the Biya regime upon the declaration of independence will be difficult. Nevertheless, the SCNC does not rule out the possibility of a 'long-drawn war' and is therefore considering the creation of a 'defensive force' in the Southern Cameroons. ${ }^{23}$

\section{ANGLOPHONE OPPOSITION TO THE PRIVATISATION OF THE CDC}

During the economic crisis there were frequent rumours in Anglophone Cameroon that the Biya government wished to privatise the CDC and sell it to French or Francophone enterprises. Although the government strongly denied such rumours, Anglophones remained on the alert, ready to act if their regional patrimony was threatened. This is a clear sign that they had lost all faith in the corrupt, authoritarian regime and were not prepared to tolerate any further attempts by the Francophone-dominated state to dismantle their cultural and economic heritage. They were particularly determined to keep control over the $\mathrm{CDC}$, the pride and economic lifeline of Anglophone Cameroon.

In June 1992, for instance, it was rumoured that the French were interested in taking over the corporation. This occurred after the Biya government, highly dependent on French support and aid, had managed to obtain a FCFA seven billion low-interest loan for the ailing company from the French CCCE. Although this loan provided much-needed capital for investment purposes, the increased control by France over the corporation was highly resented by CDC workers and managers, as well as by the wider public in Anglophone Cameroon. It was then reported in Anglophone newspapers that the CCCE wanted to take over the CDC oil palm estates, again resulting in widespread protests in Anglophone Cameroon.

This outcry against expanded French control over the corporation sharply contrasted with Anglophone sentiments regarding previous and later transfers of the management of two major CDC crops to AngloAmerican companies. Few protests were voiced in Anglophone Cameroon when the corporation entrusted management of the banana sector to the American multinational, Del Monte, in 1987. And Anglophone newspapers even lauded the agreement between the CDC and (the British) COMDEV in late 1992 which stipulated that management of the corporation's three tea estates be transferred to COMDEV for a period of ten years. Anglophones argued that these two Anglo-American companies had wide experience in plantation management. COMDEV even had such experience in Anglophone Cameroon, having satisfactorily managed the CDC from 1960 to $1974{ }^{24}$ Above all, Anglophones strongly believed that Anglo-American companies would be less inclined than French ones to dominate and exploit an Anglophone region and that their business culture fitted in well in Anglophone Cameroon.

When the government finally did announce the privatisation of the CDC on 15 July 1995, Anglophones were deeply incensed. All existing parties, associations and pressure groups in Anglophone Cameroon formed a united front to resist the government's decision. They claimed that the privatisation of the $\mathrm{CDC}$ was unjustifiable for various reasons.

First, the CDC was one of the few remaining large-scale enterprises in Anglophone Cameroon. All other regional enterprises, such as the West Cameroon Electricity Corporation (POWERCAM), the Cameroon Bank, the West Cameroon Development Agency and the West Cameroon Produce Marketing Board, had been systematically dissolved by the Francophonedominated state after reunification. 
Second, the CDC was a unique enterprise in Cameroon and the economic lifeline of Anglophone Cameroon. From its inception, the corporation had been oriented not only to capital accumulation, but also to regional development. One Anglophone columnist, Mr Jing Thomas, captured the essence of what the CDC means for Anglophones:

The CDC is unlike any other corporation. It means native lands, especially those of the Bakweri. It means jobs for Cameroonians, especially the Anglophones. It is a symbol of Anglophone survival against all odds ... If the CDC falls ... the last act of internal colonisation would have been completed. ${ }^{25}$

Third, unlike many other Cameroonian public enterprises, the CDC had always performed rather well up to the economic crisis. Moreover, the announcement of privatisation came at a time when there were bright prospects for the corporation's economic recovery following devaluation of the CFA franc.

Fourth, in accordance with the agreement between the management and the unions in 1990, the workers had injected FCFA 5.5 billion into the corporation as compulsory savings during the crisis. Therefore, the CDC could not be privatised without consulting the unions and workers.

Anglophones once again alleged that privatisation of the CDC was an ill-disguised plot to hand over the corporation to the French and the Francophones' or 'a plan of Biya to compensate his "tribesmen" and allies with a slice of the parastatal cake'. ${ }^{26}$ There were protest marches in the Anglophone towns organised by the SDF and Anglophone movements. Protesters carried banners with slogans such as 'France: hands off Anglophones' and 'Hands off or we will burn the plantations'. On 30-31 July 1994, the CAM National Executive met, condemning the privatisation of the CDC as a declaration of war against the people of Southern Cameroons and calling upon Anglophones to observe 16 August as a day of protest and solidarity with the CDC. ${ }^{27}$ In August, the Biya government sent a delegation composed of high-ranking Anglophone allies to the capitals of the two Anglophone provinces to try to calm the population. They were jeered and asked whether they would 'benefit of the spoils'.

The Bakweri, whose lands had been expropriated under German colonial rule and later leased to the CDC in 1946 for a term of 60 years, felt particularly aggrieved by the announced privatisation of the CDC. On 23 July 1994, the Bakweri chiefs and elite met at Buea, under the chairmanship of Paramount Chief S.M.L. Endeley of Buea and Paramount Chief F. Bille Manga Williams of Victoria, to discuss the implications of the government decision. They agreed to oppose the announced privatisation strongly, on the grounds that the CDC lands were Bakweri lands and thus could not be sold to non-natives without Bakweri consent. After some lengthy and passionate discussions, an ad hoc committee was elected by acclamation which was to prepare a detailed memorandum on the Bakweri position to be presented to the government and all other interested parties. ${ }^{28}$

On 4 August 1994, over 500 Bakweri elite and notables gathered at the Buea Youth Cultural and Animation Center approved the memorandum drawn up by the ad hoc committee. They later presented it to the Provincial Governor for onward transmission to President Biya. On the same day, Professor Ndiva Kofele-Kale, secretary of the ad hoc committee, was designated counsel for the Bakweri people with instructions to present their case before the United Nations and other international fora.

The Bakweri case was supported emphatically by the Anglophone movements. A strongly worded petition to the Head of State, co-signed by the Anglophone pressure groups and the Bakweri chiefs, reiterated that the Bakweri had never relinquished ownership of the CDC lands and that the corporation could not be sold without Bakweri consent. It also pointed out that the Bakweri had never been paid royalties for the use of their lands since 1946 .

Concerned about the mounting anger within the Bakweri community, the Biya government sent the above-mentioned delegation of its Anglophone allies to Buea to discuss the issue with Bakwer representatives. The delegation was led by Chief Ephraim Inoni, Deputy Secretary General at the Presidency and chief of Bakingili, a village located in the territory of a Bakweri subgroup. Though speaking on behalf of the government, he appealed to the Bakweri representatives not to forget that he was one of them. He acknowledged that there should have been prior contact between the government and the Bakweri before the announcement of the corporation's privatisation. He denied the widespread rumours in Anglophone Cameroon that the French and some high-ranking Francophones had masterminded the whole operation. While admitting that the financial situation of the CDC had improved after devaluation of the CFA franc, he argued that privatisation would enable the corporation to obtain new capital for the necessary investments in production and processing. The Bakweri Paramount Chief, S.M.L. Endeley, then took the floor. Amid thunderous applause he declared that the Bakweri were against privatisation of the $\mathrm{CDC}$ and requested Chief Inoni to report this to President Biya:

We are in a country where we like to cheat ourselves, where government hands down decisions through dictatorship ... We say no no [to privatisation], go and tell Mr Biya that he cannot afford to go down in history as the man who sold the CDC. ${ }^{29}$ 
After the delegation had returned to Yaounde, the government took no further action on the privatisation of the CDC. By the end of 1995, it was rumoured that COMDEV had shown interest in taking over the corporation. It is beyond doubt that a takeover by this renowned British corporation would be acceptable to Anglophones. Nevertheless, they would still expect COMDEV to negotiate with the Bakweri, the landowners, especially because the 60-year CDC lease will expire in 2007. Apparently the Bakweri are not inclined at present to renew the lease and are organising to reclaim the CDC lands after it expires. ${ }^{30}$

\section{CONCLUSION}

This study has highlighted the virulent resistance in Anglophone Cameroon to the government announcement of the privatisation of the CDC. It would be wrong to conclude from this opposition that Anglophones are against privatisation per se. In fact, privatisation of poorly performing public enterprises has been laid down in the programmes of most Anglophone parties, including the SDF. The petition to the Head of State, co-signed by the Anglophone pressure groups and Bakweri chiefs, also stated that

in principle, the Bakweri and other Anglophones have no quarrel with the idea of privatisation or sale of companies in which government enjoys majority control since we fully understand the logic behind such an exercise, i.e. the relocation of the management of inefficiently managed parastatals in more efficient hands. We recognise that government, as the controlling shareholder in these companies, has an obligation to the majority shareholders and the Cameroonian taxpayer to ensure that their tax revenues are not wasted in failing parastatals. ${ }^{31}$

I have argued in this study that the strong resistance of Anglophones in general and the Bakweri in particular can only be fully understood in the context of the 'Anglophone problem'. Privatisation of the CDC was perceived as a further step by the Francophone-dominated state towards destruction of the Anglophone cultural and economic heritage. This perception was strengthened by the fact that the CDC has the reputation of being one of the rare parastatals in Cameroon which from its inception has played a significant role in regional development and which had a relatively good performance record until the economic crisis. Moreover, the Bakweri, the owners of the CDC lands, were never consulted.

The Biya government has devised various strategies to cope with the 'Anglophone problem'. It has often tried to ignore or to minimise the Anglophone-Francophone divide, with reference to the unique Cameroonian colonial and post-colonial experience. Biya himself and other government officials have regularly told the Cameroonian public that "there was no Anglophone-Francophone divide during the German colonial era' and that 'Cameroon is at present a bilingual and multi-cultural nation, which is a safe guarantee for the preservation of the differential linguistic and cultural heritage of the post-German colonial era'.

In reply to the Anglophone demand for a return to the federal state, the Biya government has often stressed that the unitary state has been the result of the massive vote of the Cameroonian people voluntarily expressed during the 1972 referendum. Like Ahidjo, Biya has claimed that a unitary state is to be preferred over a federal state in the Cameroonian situation. A federal state tends to be costly, weak as far as state power is concerned, and divisive, provoking ethnic and regional sentiments rather than a national consciousness. While he has constantly declined to discuss a return to the federal state - the so-called two-state option - he appears willing to concede to a certain degree of decentralisation within the unitary state - the so-called ten-state option based on the current ten provinces in Cameroon.

The Biya government has also attempted to divide the Anglophones, capitalising on existing contradictions between the south-west and northwest elite. One of Biya's divisive tactics is to appoint south-westerners to key positions in the south-west, in response to frequent complaints of southwesterners about north-western domination over their province. Another tactic is to use his allies in the Anglophone community for the defence of the unitary state, providing them with an adequate reward for their loyal services. Paradoxically, the 'Anglophone problem' has enhanced the chances of Biya loyalists among the Anglophone elite to be appointed to government posts which used to be reserved for Francophones. Obviously, Biya's decision to enhance the position of Anglophones in the state apparatus is a strategy to belie charges that Anglophones only play second fiddle in the Francophone-dominated unitary state and, simultaneously, to attract new members of the Anglophone elite into the 'hegemonic alliance'. Such highly placed Anglophones tend to be members of the Anglophone delegations sent regularly by Biya from Yaounde to the Anglophone provinces to contest the claims of the leadership of the Anglophone movements and to defend the unitary state.

Another strategy is to cool off the mounting Anglophone opposition. The CDC privatisation case clearly shows that Biya has tried to placate the Anglophone community. He first sent an Anglophone delegation to explain government policies and investigate Anglophone and Bakweri grievances. Subsequently, he postponed the privatisation of the CDC indefinitely. $\mathrm{He}$ now seems inclined to hand over the corporation to the British COMDEV rather than to prospective French and Francophone buyers. 
Last, but not least, the Biya government continues to rely on a strategy of repression. Leaders of the Anglophone movements are regularly harassed by security forces, threatened with arrest, and subjected to travelling restrictions. Repression even seems to have been intensified in the wake of Anglophone threats to proclaim an independent Southern Cameroons state.

The privatisation protest movement is one of the recent developments in Anglophone Cameroon which have made the Biya regime painfully aware of the growing unity and determination among the Anglophones in their struggle for redress of the marginalisation and subordination of their region within the Francophone-dominated state. The regime nevertheless refuses to negotiate with the Anglophone leaders. Its arrogant denial of any 'Anglophone problem' and its resolve to defend the unitary state by all available means could lead to an escalation of Anglophone demands past a point of no return.

\section{NOTES}

1. See, for instance, B. Grosh and R.S. Makandala (eds.), State-Owned Enterprises in Africa (Boulder/London: Lynne Rienner Publishers, 1994); T. Mkandawire, 'The Political Economy of Privatisation in Africa', in G.A. Cornia and G.K. Helleiner (eds.), From Adjustment to Development in Africa: Conflict, Controversy, Convergency, Consensus? (New York: St. Martin's Press, 1994), 192-213; and R. Tangri, 'The Politics of Africa's Public and Private Enterprise', Journal of Commonwealth and Comparative Politics, 33, 2 (1995), 169-84.

2. R. Sandbrook, The Politics of Africa's Economic Stagnation (Cambridge: Cambridge University Press, 1985).

3. F. Stark, 'Federalism in Cameroon: The Shadow and the Reality', Canadian Journal of African Studies, 10, 3 (1976), 423-42.

4. N. Jua, 'Cameroon; Jump-Starting an Economic Crisis', Africa Insight, 21, I (1991), 162-70. 5. Ph. Hugon, Analyse du sous-développement en Afrique noire: L'exemple de l'économie du Cameroun (Paris: Presses Universitaires de France, 1968).

6. N. van de Walle, 'The Politics of Nonreform in Cameroon', in T.M. Callaghy and Ravenhill (eds.), Hemmed In: Responses to Africa's Economic Decline (New York: Columbia University Press, 1993), 357-97.

7. P. Konings, Labour Resistance in Cameroon (London: James Currey, 1993).

8. J.-F. Bayart, L'Etat au Cameroun (Paris: Presses de la Fondation Nationale des Sciences Politiques, 1979)

9. P.J.M. Tedga, Enterprises publiques, état et crise au Cameroun (Paris: L'Harmattan, 1990) and N. van de Walle, 'The Politics of Public Enterprise Reform in Cameroon', in Grosh an Makandala (eds.), State-Owned Enterprises, 151-74.

10. G. Faes, 'Délestage public', Jeune Afrique, 1752, 46-9.

11. Van de Walle, 'The Politics of Public Enterprise Reform in Cameroon', 162.

12. E. Ardener, S. Ardener, and W.A. Warmington, Plantation and Village in the Cameroon. (London: Oxford University Press, 1960); S.J. Epale, Plantations and Development in Western Cameroon (New York: Vantage, 1985); and Konings, Labour Resistance.

13. G. Courade, 'Marginalité volontaire ou imposee: Le cas des Bakweri (Kpe) du Mon Cameroun', Cahiers ORSTOM, sér. Sci. Hum., 18, 3 (1981-82), 357-88.

14. G.L. Beckford, Persistent Poverty: Underdevelopment in Plantation Economies of the Third World (New York/London: Oxford University Press, 1972).

15. S.G. Ardener, 'Banana Co-operatives in the Southern Cameroons', Conference Proceedings (Ibadan: Nigerian Institute of Social and Economic Research, 1958), 10-25; P. Konings, 'Contract Farming and Capital Accumulation in Cameroon: The Case of the CDC Smallholder Schemes', in P. Geschiere and P. Konings (eds.), Itinéraires d'accumulation au Cameroun (Paris: Karthala, 1993), 217-39.

16. P. Konings, 'Plantation Labour and Economic Crisis in Cameroon', Development and Change, 26, 3 (1995), 525-49.

17. P. Konings, 'Le "problème anglophone" au Cameroun dans les années 1990', Poltitique Africalne. 62 (June 1996), 25-34.

18. For the numerous Anglophone complaints, see, for instance, All Anglophone Conference, The Buea Declaration (Limbe: Nooremac Press, 1993).

19. N. Kofele-Kale, Tribesmen and Patriots: Political Culture in a Poly-ethnic African State (Washington, DC: University Press of America, 1981)

20. M. Rowlands. 'Accumulation and the Cultural Politics of Identity in the Grassfields', in Geschiere and Konings, Itinéraires d'accumulation, 71-97.

21. This was a campaign of civil disobedience organised by the opposition parties to force the Biya regime to call a national conference. It involved the stoppage of all work, all trade, and all traffic in the towns, except for Friday evenings and Saturdays, resulting in huge personal and public financial losses and an aggravation of the economic crisis.

22. Konings, 'Le "problème anglophone"', 31-2

23. West Africa, 20-26 June 1994, 1090-91.

24. Konings, Labour Resistance, $41-5$

25. Cited in Fako International, 1, 2 (Jan. 1995), 18.

26. New African, 326 (Jan. 1995), 25; and Africa International, 279/280 (Jan.-Feb. 1995), 39

CAM, 'Communiqué of the Enlarged Ex-Bureau Meeting, 30-31 July 1994' (mimeo); and CAM, 'Resolution on the Privatisation of the C.D.C' (mimeo)

28. For this memorandum, see Fako International, 1, 2 (Jan. 1995), 14-16.

29. Ibid., 16 .

30. Ibid., 17

1. Ibid, 14 


\title{
Relationship Between the State and Civil Society in the Zimbabwean Elections 1995
}

\author{
LIISA LAAKSO
}

The general elections in Zimbabwe, on 8 and 9 April 1995, were conducted in a more peaceful and regulated manner than ever before. Unfortunately, the progress in the practical arrangements of the polling was accompanied by a lack of any alternatives or even counterforces to the ruling party. If the minimum criterion for a democratic election process is an opportunity for citizens to make a political choice, one can say that in Zimbabwe the 1995 elections were the least democratic during its independence. The ruling party, the Zimbabwe African National Union (Patriotic Front), ZANU(PF), actually 'won' a majority in the parliament even before the elections started. Since only 65 seats were actually contested out of the 120 seats open for competition and since the president also has the right to appoint 30 MPs, including the eight provincial governors and ten seats reserved for chiefs, all of whom in practice are supporters of ZANU(PF), the ruling party was ensured 85 seats out of the total 150 before the election. Interestingly enough, important organisations of civil society, such as the labour unions and representatives of the business community, were very reluctant to play any role in the elections and literally avoided direct involvement with the political parties, in spite of the fact that African civil society is commonly represented as an arena for the defence and support of multi-party democracy.

This notion of African civil society stems from the fact that in the first half of the 1990s business communities and labour unions were prominently linked to regime transitions from authoritarian rule to contested elections. Michael Bratton, for instance, concluded in a recent study that '[i]n countries with pluralistic labor movements ... industrial action was at the center of mass uprising and the trade unions helped provide an organisational infrastructure for opposition movements'. Similarly, according to the same study,

an active business community plays a part in the onset of regime transitions. The often minuscule business class in African countries

Liisa Laakso, University of Helsinki, Finland

Journal of Commonwealth \& Comparative Politics, Vol.34, No.3 (November 1996), pp.218-234 PUBLISHED BY FRANK CASS, LONDON 